\title{
ICTs as Catalyst for E-Governance Initiatives in Nigeria's Economic Transformation
}

\author{
Wadzani A. Gadzama \\ ICT Unit, Fed. Poly. Mubi \\ P.M.B. 35 Mubi, Nigeria
}

\author{
Bitrus Joseph \\ Dept. of Computer Sc., Fed. Uni \\ Wukari, P.M.B.1020 Wukari, Nigeria
}

\author{
Ogah U.S. \\ Dept. of Computer Sc., Fed. Poly \\ Mubi, P.M.B. 35 Mubi, Nigeria
}

\begin{abstract}
There is no refutation to the fact that Information and Communication Technologies (ICTs) has enabled government officials to offer better services which can be utilized to achieve economic development in different countries of the world. The discussions in the paper are centered on ICT and E-governance and their resultant effects on Nigeria's economic transformation. It can be argued that the huge success achieved in the country's information and communication technology sector over the years and the need for effective governance led to the emergence of Egovernance in Nigeria. At this point, it is imperative to note that e-governance involves the application of electronic technologies and ICTs to reinforce public services, government administrative procedures, democratic activities, associations among citizens and the general civil society, private sector, and the state. The data used in this paper were from articles, journals and paper presentations. This paper also reviews the major deficiencies that have contributed to Nigeria's low ranking in e-Government delivery to its citizens despite the increase use of ICT in the country and suggests how this situation can be improved.
\end{abstract}

\section{Keywords}

Economic Development, E-governance, ICT, Economic Transformation

\section{INTRODUCTION}

Essentially, the Information and Communication Technologies (ICTs) are continuously changing the manner in which citizens; government officials, business enterprises and other stakeholders within a country communicate and interact with others all over the world. Today, in addition to their impacts on the welfare of citizens, families, and general public, the impact of ICT on the public service sectors of different countries have firmly contributed to the stability of the global economy [1]. Based on the above arguments, the diffusion of ICTs into different facets of human endeavor is said to be one of the basic building blocks of modern society. [2] Proposed that ICTs were known to possess remarkable administrative capabilities and potentials and therefore it is applicable in government processes. It was observed by [3] that several countries around the globe are making effort to rejuvenate their public administration system in a bid to make it more transparent, proactive, efficient, and in particular to be more service oriented. To achieve this transformation agenda, governments are introducing innovations in their organizational structure, practices, capacities, and in the ways they mobilize, deploy and exploit the human capital and information, technological and financial resources for service delivery to citizens. In this situation, the appropriate application of ICT plays a vital role in improving the goals of the public sector and in creating a very conducive environment for socio-economic growth. [4] Shares similar view with [5] on the fact that ICTs have revolutionized the global process of governance and the ways we live, contemporary businesses are carried out easily with the aid of modern communication facilities. This trend has given birth to the evolution of the present-day electronic processes such as e-commerce, e-government, e-medicine, e-banking and eeducation etc. Another study [6] suggested that the use of information and communication technologies have transformed the procedure and process of governance across the world; thereby turning the present age into cyberspace or global village as some people fondly refer to it.

The origin of e-Governance dates back to the beginning of the 21 st century [3]. It can be gathered from a study by [7] that eGovernance comprises a wider vision of applications of ICT to reinforce and support the process of good governance as well as to inspire citizens to actively grab the opportunities to freely receive information. The practice of e-Governance was believed to have originated at the beginning of 21 st century, mostly as a copy of e-commerce into public sector. All intentions at that time were directed towards the presence of the public services on the Internet [6]. Some government agencies in Nigeria were found to have adopted the eGovernance platform via e-payment systems which encourage citizens to pay their taxes; it can be inferred that the introduction of Integrated Tax Administration Systems (ITAS) into the Nigerian economy in 2013 has positioned Nigeria fully into the confederation of nations that employs eGovernance as a taxation mechanism [8]. The authors [9] and [10] in their researches gave a simplified definition of eGovernance as the application of electronics technology and ICTs in government procedure, administration and management processes and also to reinforce public services, government administrative procedures, democratic activities, associations among citizens and the general civil society, private sector, and the state.

\section{REVIEW OF RELATED LITERATURES}

Information technology has gone mobile cutting across different areas of human endeavor, which comprises of the management information systems used to support decisionmaking and for business process automation [11]. The information technology's capability to support the decisionmaking process can be utilized by government officials that head the different public service sectors in Nigeria to improve the government procedures, and management processes. EGovernance refers to the application of Internet services and information and communication technology to improve the accessibility to information regarding government operations, distribute government services to the public, which in return 
brings about improvement in government services thereby enabling government to serve her citizens better as compared to the traditional mode of governance [12]. Various scholars have provided different definitions of e-Governance. Egovernance refers to the public sector's use of ICTs with the aim of enhancing information and service delivery, encouraging citizen participation in the decision-making process and making government more accountable, transparent and effective [13]. According to [14] eGovernance is an ICT-enabled route to achieving good governance through the introduction of governmeq2nt websites and portals to provide free flow of information and also the simplification of governmental processes, for governments and their citizens. [15] Viewed that government plans, policies and subsidies shall extend to everyone via eGovernment portals. All the information that needs to be communicated to citizens is made accessible to such citizens by their government via ICT-driven e-Government initiatives. [16] observed that the scope of e-Governance has gone beyond just having a government website on the Internet; the tactical objective of e-governance is to buttress and simplify governance for all the stakeholders such as governments, citizens and businesses of a country. The use of Information and Communication Technologies helps in connecting all the stakeholders and support governance processes and activities. E-governance also refers to computerization of current government procedures [17].

The potential of ICT to enhance Nigeria's economic growth have been identified in the [18] which reported that in order to make Nigerian economy more competitive in the 21 st century global economy, its industrial policy must be linked to a digital-led strategy for growth. The ERGP will build on The Smart Nigeria Digital Economy Project to increase the contribution from ICT and ICT-enabled activity to Nigeria's Gross Domestic Product (GDP). The continued improvement in the implementation of e-Government initiatives and their usage by governments and their citizens all over the world has remained a key factor in information delivery diversification. It was examined by [19] that the growing power of ICT has also provided governments to have the flexibility of providing services and information resources to citizens through multiple channels. These channels could be websites, portals, government agencies social media pages television and radio programs among others.

\section{RESEARCH METHODOLOGY}

The authors strictly used relevant journals, conference proceedings, and government websites in eliciting information and the needed data for this paper.

\section{BENEFITS OF E-GOVERNANCE}

There are numerous benefits of e-Governance implementation in developing countries like Nigeria such as greater efficiency, better public services and the reduction in the costs of administrative procedures. E-governance is capable of making government activities to be better, more quickly, cheaper and transparent [20]. According to [21], another benefit of e-Governance is that it has facilitated the use of information technology for educational purposes. A study by [22] found that one of the vital features of e-Governance is the manner in which it draws citizens and businesses within a country nearer to their governments. This phenomenon will enable governments to relate closely with citizens thereby promoting socio-economic transformations of a country. [23] observed that other benefits of e-Government include reduction in the overall administrative and development difficulties in both developed and developing countries. [21]
Also opined that the primary benefits of e-Governance include efficiency and its ability to reduce corruption through automation.

\subsection{E-Governance Development and Initiatives in Nigeria}

The history of e-Governance in Nigeria dates back to 2000 when the Nigerian National Information Technology (NNIT) policy was formulated. The idea behind this policy formulation was to make Nigeria an IT-enabled country in Africa and a major competitor in the information society; and also to harness the power of Information Technology in education, creation of wealth, poverty eradication, job creation, governance, health and agriculture [24]. Additionally, Nigerian government in compliance with her target of transforming the country into a digitized society had embarked on an aggressive IT policy formulation. The first step taken by Nigeria government that led to the birth of eGovernance in the country due to ICT development is the enactment of the national information technology policy in the month of March 2001 which paves way for the establishment of National Information Technology Development Agency [25]. E-Government projects started in Nigeria as an initiative of the National Information Technology Development Agency (NITDA) fashioned in a public private partnership approach that seeks to collaborate between government and the private sector with the aim of enabling the public sector to provide better services [7].

[6] Observed that the first appearance of e-governance in Nigeria is linked to the return of democracy in 1999 in which the development of government websites represents the first approach taken by government to establish their online presence. Despite the establishment of online presence by Nigerian government as proved by the introduction of government websites in the country, their commitments towards harnessing the benefits of such initiatives does not meet the global standard because some government organizations do not have a website. According to [26] only twenty-three out of the thirty-six states in Nigeria representing $64 \%$ had official websites which provide textual information generally while few of them offer downloadable contents and active online interactions.

Previous researches confirmed that Nigeria has employed eGovernance in different sectors of her economy; [8] observed that Nigeria was numbered among the countries that engage eGovernance as a tax collection mechanism when the Integrated Tax Administration System (ITAS) was introduced by Nigerian government in 2013 while [27] argued that one famous organization in Nigeria that utilizes the potentials of ICT in governance is the Independent National Electoral Commission (INEC) via the use of technologies like Electronic Voters Register (EVR), Automatic Fingerprints identification System (AFIS) and Smart Card Reader (SCR) which were employed during the 2015 general election. [6] shares similar view with [7] that other real time and cost effective applications of e-Governance in Nigeria include: Nigerian Customs Assycuda Programme, the computerization Resident Permit introduced by the Nigerian Immigration Service, online checking of results by examination bodies like the West Africa Examination Council (WAEC), National Examination Council (NECO) and Joint Admission and Matriculation Board (JAMB) also the postings of National Youth Service Corps (NYSC) corps members. According to [12] other organizations and agencies of Nigerian government that have adopted and employed e-Governance as a driver for good governance include: 
i. Abuja Geographical Information System (AGIS) online land registration.

ii. Post-cash of Nigeria postal service.

iii. National Open University of Nigeria (NOUN)

iv. Electronic Voters Registrations.

v. Online payment of fees in most tertiary institutions

vi. Online display of admission into most Nigerian Universities

The list of organizations and agencies of Nigerian government that have employed e-Governance as a driver for good governance today is growing at a high speed as can be seen in the recent online recruitment of agencies like N-Power, FRSC, Nigerian army etc.

\section{MAJOR HINDRANCES TO E- GOVERNANCE IMPLEMENTATION IN NIGERIA}

\subsection{Low Rate of ICT Literacy}

One of the major factors affecting the success of eGovernment implementation in Nigeria is the low rate of ICT literacy for example, while there is much publicity about the use of ICT among youths, the overall consciousness among the citizens about ICTs is low [25].

\subsection{Inadequate e-Governance Policy Implementation}

Another hindrance to the implementation of e-Government in Nigeria is the weak implementation of e-Government policies caused by political leadership failures [13].

\subsection{Problems of Power Supply}

One of the strongest set back that affects the progress of egovernance in Nigeria is the epileptic power supply. According to previous research by [5], the irregular or nonexistent nature of electricity supplies in Sub Saharan Africa (SSA) where Nigeria belongs is another hindrance to the use of the ICTs, especially outside the main towns; hence the irregular supply of electricity contributes a lot to the failure of e-Governance implementation in Nigeria.

\subsection{Digital Divide}

Digital divide denotes the gap in opportunity between those who have access to computers and Internet and those who do not. The competence to use computers and the Internet has become a vita factor that guarantee the success of egovernment implementation, and the absence of such skills may lead to marginalization, sidelining or even social exclusion [28].

\subsection{Poor Monetary Allocations for ICT infrastructures}

Another factor which led to failures of e-Governance implementation in Nigeria is that Federal government usually approves tiny budgetary allocations for ICT development in the country. This trend of government's inability to meet the financial requirement for ICT development threatens the success of implementing e-Governance projects in the country [29].

In line with the challenges and hindrances to e-Government implementation in Nigeria outlined above, this paper has carried a survey of Nigeria's E-Government Development Index (EGDI) and rankings for a period of twelve years at an interval of 2 years from 2008 to 2020 as shown in table 1 below.
Table 1 Nigeria's E-Government Development Index (EGDI) and ranks from 2008 to 2020

\begin{tabular}{|l|l|l|}
\hline Period & $\begin{array}{l}\text { E-Government } \\
\text { Development } \\
\text { Index (EGDI) }\end{array}$ & Rank \\
\hline 2008 & 0.3063 & 136 \\
\hline 2010 & 0.2687 & 150 \\
\hline 2012 & 0.2676 & 162 \\
\hline 2014 & 0.2929 & 141 \\
\hline 2016 & 0.3291 & 143 \\
\hline 2018 & 0.3807 & 143 \\
\hline 2020 & 0.4406 & 162 \\
\hline
\end{tabular}

(Source: [3], [19], [32], [33], [34], [35], [36])

It can be observed from table 1 that Nigeria's e-Government global rank was higher in 2008 (136 out of 193) compared to 2020 (162 out of 193) the above table is represented graphically as shown in figure 1 below.

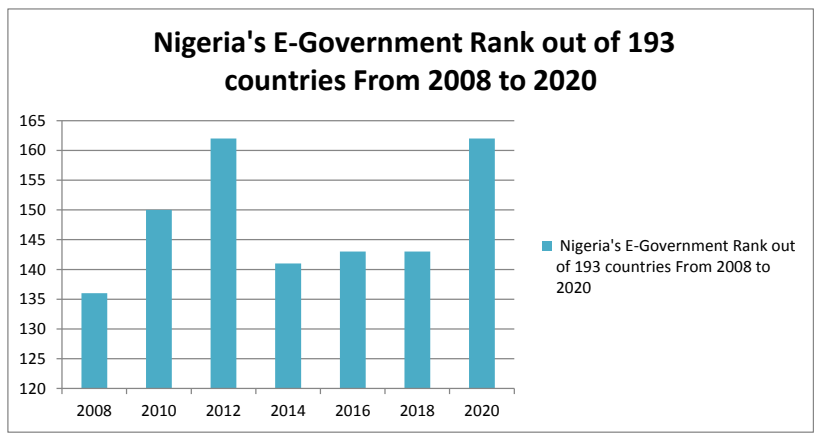

(Source: Generated from the data of Table 1 above)

\section{RECOMMENDATIONS}

In order to harness the power of the innovations in ICT and implement an effective, reliable and responsive e-Governance system in Nigeria, this paper wishes to recommend the following measures which Nigerian government should adopt

i. Nigerian government should in addition to the ICT policy formulations such as the introduction of computer studies in Nigerian education sector make adequate provision of ICT facilities within the reach of all education institutions so that ICT practical lectures can be carried out effectively.

ii. All Ministries, Departments and Agencies (MDA) of Nigerian government must follow the steps adopted by other countries in driving their eGovernment projects through the creation of websites which were linked to a single portal. For example, [30] reported that at the beginning of 2000, the Colombian President directed all federal government agencies to create Internet sites representing their services to the Colombian citizenry, which are now linked through a single 
portal; this will enable the Nigerian government to have a centralized portal.

iii. All the tiers of Nigerian government (Federal, State, and Local government) should promote the campaign for all their ministries, departments and agencies in order to have a common integrated national network where information regarding government businesses and service delivery are made available to Nigerian citizenry.

iv. Nigerian government should ensure that ICT services are available, accessible and affordable to all MDAs and her citizens

v. Federal government should ensure that secured Internet data connectivity should be made accessible to Nigerian citizens residing in the urban and rural areas at a lower cost

vi. One of the hindrances to the successful implementation of e-Governance project in Nigeria is the low rate of ICT literacy which can be addressed by embarking on formal and informal ICT training for all.

\section{CONCLUSION}

E- Governance which denotes the application of electronics technology and ICTs in government procedure, administration and management processes when completely implemented in Nigeria, will enable its citizens to carry out government businesses more effectively on the Internet via dedicated government websites and portals without a citizen's physical presence at government offices and this will reduce bureaucratic procedures in governance. Successful egovernance implementation in any country has the capacity to boost the interaction between government and citizens who are the key government clientele [31]; this in turn will lead to the establishment of citizen driven government that is transparent, effective and accountable.

\section{ACKNOWLEDGMENTS}

The authors of this paper wish to acknowledge and thank all the authors whose works were consulted to the completion this paper.

\section{REFERENCES}

[1] Kamal, M.,Trish, A., Liezl, D. G., Omri,V. Z., Hugo, L., Kirsten,K., \& Debashis,N. (2012)The Transformational Use of Information and Communication Technologies in Africa: ICTs for ModernizingGovernment in Africa, eTransform Africa: 114-128 Accessed on 13 March 2018, Retrieved from http://www.eTransformAfrica.org

[2] Yildiz, M. (2007) E-Government research: Reviewing the literature, limitations, and ways forward, Government Information Quarterly, 24: 646-665

[3] United Nations E-government Survey (2008) From Egovernment to Connected Governance: United Nations Department of Economic and Social Affairs. Retrieved from https://publicadministration.un.org

[4] Ajayi, I. A. \& Ekundayo, H. T. (2009) The Application of Information and Communication Technology in Nigerian Secondary Schools: International NGO Journal 4 (5): $281-286$

[5] Ngulube, P. (2007) The Nature and Accessibility of E-Government in Sub Saharan Africa: International Review of Information Ethics 7: 1-13
[6] Fatile, J. O. (2012) Electronic Governance: Myth or Opportunity for Nigerian Public Administration, International Journal of Academic Research in Business and Social Sciences 2(9): 122-140

[7] Suleiman, M., Mohammad, K. A., \& Amina, B. (2010) eGovernment in Nigeria: A Catalyst for National Development, Being a Paper, Presented at Fourth International Conference on Development Studies, University of Abuja, held on $14^{\text {th }}-15^{\text {th }}$ April , 2010 at FCT Abuja Nigeria

[8] Stephen, A.O., Ayodutun, I., Iyoha, F.O., Charles, K.A., \& Daniel G. (2017) Role of e-Governance in Nigeria's Tax System: Strategy Perspective to Enhancing Compliance, The Social Sciences 12(8): 1482-1486

[9] Frank, B. \& Regina, C. (2012) Defining e-Governance: e-Service Journal 8(2): 3-25, Published by Indiana University Press

[10] Yusufu, G. \& Wadzani, A. (2013) E- Government in Practice: Information and Communication Technology in Local Government Administration in Nigeria (The Case of Askira/Uba Local Area of Borno State), International Journal of Arts, Administration and social sciences, 5: 605-611

[11] Krume, N. (2012) The Role of Information Technology in the Business Sector: International Journal of Science and Research 3(13): 303-309

[12] Asogwa, B. E. (2011) The state of e-Government readiness in Africa: A Comparative Web Assessment of Selected African Countries. Journal of internet and Information System 2(3): 43-57

[13] Richard, A. O. \& Eme, O. I. (2015) Electronic Governance \& Administration in Nigeria: Prospects \& Challenges, Arabian Journal of Business and Management Review 5(3): 18-26

[14] Felicia, O. O (2010) E-Governance As A Tool For Public Sector Development In Nigeria: International Journal of Research in Arts and Social Sciences 2: 493-511

[15] Mohammad, A. S., \& Sriram, B. (2015) Major challenges in developing a successful e-government: A review on the Sultanate of Oman, Journal of King Saud University, Computer and Information Sciences 27: 230 235

[16] Basu, S. (2004) E-Government and Developing Countries: An Overview, International Review of Law Computers \& Technology, 18 (1)

[17] Adarsh, S. P., Bhrantav N. V., \& Pravinkumar, R. P. (2012) Importance of E-Governance in India and Challenges to Implement: International Journal of Computer science and Technology, 3(2): 179-181

[18] Economic Recovery \& Growth Plan, February 2017: Federal Republic of Nigeria, Ministry of Budget \& National Planning, 2017-2020:

[19] United Nations E-government Survey (2012) Egovernment for the people, United Nations Department of Economic and Social Affairs. Retrieved from https://publicadministration.un.org

[20] Nchuchuwe, F. F., \& Akhakpe, I. B. (2015) EGovernance and Socio-Economic Development in Nigeria: Limitations and Possibilities, Proceedings of 
Covenant University Conference on E-Governance in Nigeria (CUCEN) held on $10^{\text {th }}-12^{\text {th }}$ June, 2015

[21] Emma, E.O. C., Okeke, C., \& Faith, O. (2018) Correlation between E-Governance and Service Quality: Interrogating the Success of E-Governance in JAMB Nigeria, Journal of Banking and Finance Management 1(1): 9-38

[22] Zhiyuan, F. (2002) E-Government in Digital Era: Concept, Practice, and Development, International Journal of the Computer, the Internet and Management 10(2): 1-22.

[23] Wisdom, K. T \& Nana, Y. A. (2014) Challenges of Implementing and Developing E-Government: A Case Study of the Local Government System in Ghana: International Journal of Computer Science and Telecommunications 5(8): 39-48

[24] Ugochukwu, D. A., \& Lawrence, I. E. (2015) EGovernance and Its Implementation Challenges in the Nigerian Public Service: Acta Universitatis Danubius 7(1): 30-42

[25] Edward, O., \& Charles, O. (2014) New Wine in Old Wine Skin: An Exploration of Major Constraints to EGovernment Implementation in Nigeria, European Scientific Journal 10(14): 481-487

[26] Oni, A.,Okunoye, A. \& Mbarika, V. (2016) Evaluation of E-Government Implementation: The Case of State Government Websites in Nigeria, The Electronic Journal of e-Government 14(1): 48-59

[27] Ayeni, T.P. \& Esan, A.O. (2018) The Impact of ICT in the Conduct of elections in Nigeria: American Journal of Computer Science and Information Technology, 6(1): $1-6$.

[28] Alshehri, M. \& Drew, S. (2010) E-Government Fundamentals: Proceedings of the International Association for Development of the Information Society (IADIS) Conference on ICT, Society and Human Beings 2010: 35-42
[29] Azeez, N.A., Abidoye, A.P., Adesina, A.O., Agbele, K.K., Venter, I.M., \& Oyewole, A.S. (2012) Threats to E-Government Implementation in the Civil Service: Nigeria as a Case Study, The Pacific Journal of Science and Technology 13

(1):398-402

[30] InfoDev (2002) The E-Government Handbook for Developing Countries: A Project of InfoDev and The Center for Democracy \& Technology

[31] Joseph, C. (2018) A Review of E-government Development in Africa: A case of Zambia. Journal of e-Government Studies and Best Practices, 2018:1-13

[32] United Nations E-government Survey (2010) Leveraging E-government at Time of Financial and Economic Crisis, United Nations Department of Economic and Social Affairs. Retrieved from https://publicadministration.un.org

[33] United Nations E-government Survey (2014) Egovernment for the Future We want, United Nations Department of Economic and Social Affairs. Retrieved from https://publicadministration.un.org

[34] United Nations E-government Survey (2016) Egovernment in Support of Sustainable Development, United Nations Department of Economic and Social Affairs. Retrieved from https://publicadministration.un.org

[35] United Nations E-government Survey (2018) Gearing Egovernment to Support Transformation Toward sustainable and Resilient Societies, United Nations Department of Economic and Social Affairs. Retrieved from https://publicadministration.un.org.

[36] United Nations E-government Survey (2020) Digital Government in the Decade of Action for Sustainable Development with addendum on COVID-19 Response, United Nations Department of Economic and Social Affairs. Retrieved from https://publicadministration.un.org. 